\begin{tabular}{|l|l|l||}
\hline \multicolumn{2}{|c|}{ PublisherInfo } \\
\hline \hline PublisherName & $:$ & BioMed Central \\
\hline \hline PublisherLocation & $:$ & London \\
\hline \hline PublisherImprintName & $:$ & BioMed Central \\
\hline \hline
\end{tabular}

\title{
zTNF4 blockade in murine lupus
}

\begin{tabular}{|l|l|l||}
\hline \multicolumn{2}{|c|}{ ArticleInfo } \\
\hline \hline ArticleID & $:$ & 172 \\
\hline \hline ArticleDOI & $:$ & $10.1186 /$ ar-2000-66824 \\
\hline \hline ArticleCitationID & $:$ & 66824 \\
\hline \hline ArticleSequenceNumber & $:$ & 129 \\
\hline \hline ArticleCategory & $:$ & Paper Report \\
\hline ArticleFirstPage & $:$ & 1 \\
\hline \hline ArticleLastPage & $:$ & 4 \\
\hline \hline & & RegistrationDate : 2000-7-18 \\
\hline ArticleHistory & $:$ & OnlineDate \\
\hline \hline ArticleCopyright & $:$ & Current Science Ltd2000-7-18 \\
\hline \hline ArticleGrants & $:$ & \\
\hline \hline ArticleContext & $:$ & 130753311 \\
\hline \hline
\end{tabular}


Chaim Putterman, Aff1

Aff1 Albert Einstein College of Medicine, New York

\section{Keywords}

BAFF/zTNF4, BCMA, systemic lupus erythematosus, TACI, TNF receptor family

\section{Context}

In a recent paper report, I discussed an article describing mice overexpressing BAFF (also known as zTNF4, BLyS, TALL-1, and THANK), a newly described member of the TNF family. BAFF transgenic mice displayed a significant expansion of the B cell compartment, due to increased proliferation and/or prolonged B cell survival. Furthermore, lupus-like autoimmune features were found in BAFF-transgenic mice. Interfering with the interaction between BAFF and its ligand could be of great value in the treatment of autoimmune disease. To confirm a role for BAFF in lupus, identify its receptor(s), and examine if blocking BAFF-BAFF receptor interactions is effective in the treatment of murine SLE.

\section{Significant findings}

The zTNF4-transgenic mice were generally similar to the previously described BAFF-transgenic mice. FACS analysis showed a significant increase in the number as well as proportion of $\mathrm{B} 220^{+} \mathrm{B}$ cells in the spleen and lymph nodes in transgenic mice as compared to controls. In contrast to BAFFtransgenic mice, the zTNF4-transgenics contained large numbers of B-1a cells in the spleen. While the number of splenic $\mathrm{T}$ cells was unchanged, $\mathrm{CD} 4^{+}$and $\mathrm{CD}^{+} \mathrm{T}$ cells were in an activated state. Serum $\mathrm{IgM}$ and $\mathrm{IgG}$ were increased several fold in the majority of transgenic mice. Older zTNF4-transgenic mice developed anti-double-stranded (ds) DNA antibodies, several at high titer. In addition, proteinuria and glomerulonephritis were found. Serum zTNF4 levels increased with age in the lupus-prone MRLlpr/lpr and B/W mouse models, and were highest in the most severely affected mice. Two orphan TNF receptor family molecules, TACI and BCMA, were idenified as receptors for zTNF4. TACI-Ig prevented the binding of zTNF4 to human B cells, as well as its stimulatory effects on murine and human B cells in vitro. Administration of TACI-Ig to B/W mice from 21 to 26 weeks of age delayed the onset of severe proteinuria for up to 10 weeks after treatment was stopped. Importantly, survival increased to $100 \%$ at 38 weeks in treated mice compared with only $47 \%$ in controls; however, there were no differences in anti-dsDNA antibody titers. After TACI-Ig treatment, the percentages of 
peripheral blood B cells was significantly decreased (by 53\% at the high treatment dose) at week 28 , but returned to control levels by week 37 .

\section{Comments}

This paper adds to growing literature substantiating a role for zTNF4/BAFF in autoimmunity, specifically in lupus. Mice overexpressing this molecule, a member of the tumor necrosis factor (TNF) ligand family, have increased numbers of B cells and secrete high levels of pathogenic antibodies. It is important to note, however, that the phenotype of zTNF4/BAFF transgenic mice is not identical to human lupus; for example, lyphopenia rather than lymphocytosis is a common finding in the human disease. Novel findings by Gross et alinclude the identification of TACI (transmembrane activator and CAML-interactor) and BCMA (B-cell maturation antigen) as the receptors for zTNF4; however, any differential effect of ligand binding to these receptors was not reported. The demonstration that giving soluble receptor in the form of a fusion protein of TACI with Fc ameliorates murine lupus further implicates zTNF4 in the pathogenesis of the disease, and suggests a novel therapeutic approach. Immunogenicity of the fusion protein was not addressed in this study, but of course will need to be looked at before applying this form of treatment to humans. Therapeutic intervention in the form of a decoy receptor for TNF and related molecules has been successfully used in several experimental autoimmune models, as well as in human rheumatoid arthritis. Multiple mediators and cells are involved in systemic lupus erythematosus (SLE), and it seems unlikely that interfering with a single ligandreceptor interaction will be sufficient to cure all of the protean manifestations of the disease. Nevertheless, decoy receptors for TNF and related molecules may be promising options in the future treatment of autoimmune disease.

\section{Methods}

Mice overexpressing zTNF4 under the control of a lymphoid-specific promoter were generated and analyzed for changes in B cells and T cells, as well as for renal disease. Transgene expression was verified by PCR and high levels of zTNF4 by ELISA. Genes for zTNF4 receptors were identified by staining COS7 cells, transfected with a cDNA library from a B cell line, with labeled zTNF4 (receptor cloning). A soluble version of one receptor was created by fusing the extracellular domain of TACI to the Fc portion of human IgG1 (TACI-Ig), and was administered to lupus-prone NZB x NZW F1 (B/W) mice. 


\section{References}

1. Gross JA, Johnston J, Mudri S, Enselman R, Dillon SR, Madden K, Xu W, Parrish-Novak J, Foster D, Lofton-Day C, Moore M, Littau A, Grossman A, Haugen H, Foley K, Blumberg H, Harrison K, Kindsvogel W, Clegg CH: TACI and BCMA are receptors for a TNF homologue implicated in B-cell autoimmune disease. Nature. 2000, 404: 995-999.

This PDF file was created after publication. 